\title{
Calcitonin Gene-Related Peptide Receptor Antagonist BIBN 4096 BS for the Acute Treatment of Migraine
}

\author{
Jes Olesen, M.D., Hans-Christoph Diener, M.D., Ingo W. Husstedt, M.D., \\ Peter J. Goadsby, M.D., David Hall, Ph.D., Ulrich Meier, Ph.D., \\ Stephane Pollentier, M.D., and Lynna M. Lesko, M.D., \\ for the BIBN 4096 BS Clinical Proof of Concept Study Group
}

A BSTRACT

From the Department of Neurology, Glostrup Hospital, University of Copenhagen Copenhagen, Denmark (J.O.); the Department of Neurology, University of Essen, Essen, Germany (H.-C.D.); the Department of Neurology, University Hospital, Münster, Germany (I.W.H.); the Institute of Neurology, London (P.J.G.); Boehringer Ingelheim Pharmaceuticals, Ridgefield, Conn. (D.H. L.M.L.); and Boehringer Ingelheim Pharma, Ingelheim, Germany (U.M., S.P.). Address reprint requests to $\mathrm{Dr}$. Olsen at the University of Copenhagen, Department of Neurology, Glostrup Hospital, 2600 Glostrup, Copenhagen, Denmark, or at jeol@ glostruphosp.kbhamt.dk.

N Engl J Med 2004;350:1104-10. Copyright @ 2004 Massachusetts Medical Society.

\section{BACK GROUN D}

Calcitonin gene-related peptide (CGRP) may have a causative role in migraine. We therefore hypothesized that a CGRP-receptor antagonist might be effective in the treatment of migraine attacks.

\section{METHODS}

In an international, multicenter, double-blind, randomized clinical trial of BIBN 4096 BS, a highly specific and potent nonpeptide CGRP-receptor antagonist, 126 patients with migraine received one of the following: placebo or $0.25,0.5,1,2.5,5$, or $10 \mathrm{mg}$ of BIBN 4096 BS intravenously over a period of 10 minutes. A group-sequential adaptive treatment-assignment design was used to minimize the number of patients exposed.

\section{RESULTS}

The 2.5-mg dose was selected, with a response rate of 66 percent, as compared with 27 percent for placebo $(\mathrm{P}=0.001)$. The $\mathrm{BIBN} 4096 \mathrm{BS}$ group as a whole had a response rate of 60 percent. Significant superiority over placebo was also observed with respect to most secondary end points: the pain-free rate at 2 hours; the rate of sustained response over a period of 24 hours; the rate of recurrence of headache; improvement in nausea, photophobia, phonophobia, and functional capacity; and the time to meaningful relief. An effect was apparent after 30 minutes and increased over the next few hours. The overall rate of adverse events was 25 percent after the 2.5-mg dose of the drug and 20 percent for the BIBN 4096 BS group as a whole, as compared with 12 percent for placebo. The most frequent side effect was paresthesia. There were no serious adverse events.

CONCLUSIONS

The CGRP antagonist BIBN 4096 BS was effective in treating acute attacks of migraine. 
M IGRAINE IS AMONG THE MOST COMmon disorders, with a one-year prevalence of 12 percent. ${ }^{1,2}$ According to the Global Burden of Disease Study conducted under the auspices of the World Health Organization, migraine is one of the leading causes of disability. ${ }^{3}$ Although the availability of triptans - selective agonists of serotonin (5-hydroxytryptamine [5-HT]) receptors that activate $5-\mathrm{HT}_{1 \mathrm{~B}}$ and $5-\mathrm{HT}_{1 \mathrm{D}}$ $\left(5-\mathrm{HT}_{1 \mathrm{~B} / 1 \mathrm{D}}\right)$ receptors - has greatly improved the acute treatment of migraine, many patients have no response to triptans, complete pain relief is the exception rather than the rule, and their vasoconstrictive properties cause concern among doctors and patients alike. Thus, new approaches to the management of migraine are needed. ${ }^{4}$

Calcitonin gene-related peptide (CGRP) is one of several neuropeptides found in the human trigeminal sensory neurons. It is found in both the pericranial vascular nerves and the trigeminal ganglion. ${ }^{5}$ CGRP is a potent dilator of cerebral and dural vessels,${ }^{6}$ and it is involved in meningeal dural vasodilation. ${ }^{7}$ Cranial CGRP levels are elevated in patients with migraine, ${ }^{8}$ and an infusion of CGRP can trigger a migraine attack. ${ }^{9}$ We therefore hypothesized that CGRP antagonists might be effective in the treatment of acute migraine.

BIBN 4096 BS is a nonpeptide CGRP-receptor antagonist with an extremely high affinity and specificity for the human CGRP receptor. ${ }^{10}$ Extensive experiments in animals, in vitro studies of human cephalic arteries, and studies in humans have shown that it potently blocks the effect of CGRP. ${ }^{11}$ BIBN 4096 BS is the first CGRP antagonist available for clinical studies. In this context, we planned a proofof-concept study, using a double-blind, randomized, placebo-controlled design. The primary aims were to evaluate the efficacy of this new treatment and to provide preliminary data on its safety and tolerability.

\section{METHODS}

The study was performed in accordance with the Declaration of Helsinki and under the principles of Good Clinical Practice. The trial was approved by all ethics committees of the participating countries, and all patients gave written informed consent. The study was conducted in 16 centers in Denmark, Germany, the Netherlands, and the United Kingdom from February to December 1999. The study was designed by the sponsor in consultation with the investigators. Data management and analysis were performed by the sponsor and fully reported to the investigators. The article was written chiefly by two academic authors, with all others contributing.

\section{PATIENTS}

Patients who met all of the following criteria were considered for enrollment: receipt of a diagnosis of migraine (with or without aura) according to the criteria of the International Headache Society ${ }^{12}$ at least one year before enrollment, an age at the onset of migraines of no more than 50 years, a current age of 18 to 65 years, a history of one to six migraines per month for the preceding six months, and the ability to give written informed consent. Patients with severe medical or psychiatric illness, overuse of any medication, or frequent nonmigraine headaches were excluded.

\section{STUDY DESIGN}

A group-sequential adaptive treatment-assignment design was chosen to achieve the trial's objectives with a comparatively low number of patients and, especially, to minimize exposure of patients to nonefficacious doses. The goal of this sequential procedure is to identify the lowest dose of a drug that is superior to placebo (the minimal effective dose), as evidenced by a rate of response of at least 60 percent. The study design is based on group-sequential methods for the interim analysis of an ongoing trial, ${ }^{13}$ and so-called up-and-down adaptive assignment designs are used to investigate the efficacy of a range of doses. ${ }^{14} \mathrm{~A}$ simple up-and-down design has previously been used in the study of potential treatments for acute migraine. ${ }^{15}$

Groups of six patients presenting with moderate-to-severe migraine were treated, with four patients being randomly assigned to receive one dose of BIBN 4096 BS and two patients to receive placebo. With the BIBN 4096 BS dose of $1.0 \mathrm{mg}$ used as the base line, the dose for each succeeding group was determined on the basis of the response observed in the preceding group. The dose in the next group was decreased if at least three of the four patients in the BIBN 4096 BS group had a response; otherwise, the dose was increased. At the highest or lowest dose, the rule was modified to avoid treatment outside the target range. If results for the preceding six patients were not available to guide the dose used for the next group, the next lower dose was used. This up-and-down process was to be terminated when one of the doses satisfied the selec- 
tion criteria: the dose had been tested in at least five groups, and the response was observed in at least four groups among at least three of the four patients in each group who received BIBN 4096 BS. This approach ensured that at least 20 patients were treated with the selected dose and at least 18 patients received placebo. If the threshold for stopping was reached before three groups had been treated with the highest dose, then additional groups were to be added until a minimum of 12 patients had received the 10-mg dose.

\section{PROCEDURES}

After the first screening visit, patients returned when they had an acute migraine attack. They were then included in the study provided the attack had not lasted more than six hours, was moderate to severe, and was not improving. Base-line assessments included history taking, physical examination, measurement of vital signs, a pregnancy test for women of childbearing potential, and 12-lead electrocardiography. The pain associated with the migraine during the study was rated as mild, moderate, or severe. The presence or absence of nausea, vomiting, photophobia, and phonophobia was assessed, and the Clinical Disability Scale completed. Investigators used a telephone call-in system set up by a central randomization center. After randomization, each patient received a 10 -minute intravenous infusion of placebo (xylitol) or of 0.1, 0.25, $0.5,1,2.5,5$, or $10 \mathrm{mg}$ of BIBN 4096 BS. Each patient was treated only once. Use of placebo has advantages in pain studies ${ }^{16}$ and is generally recom- mended in migraine trials ${ }^{17}$ because of variable rates of response to placebo in different trials ${ }^{18}$ and because it poses no risk to patients except that it delays treatment for two hours. Base-line measures of efficacy were repeated 30 minutes and 1,2 , and 4 hours after the infusion was begun and again after 24 hours by means of a telephone interview with the patient. A stopwatch was used to measure the time to meaningful relief.

Adverse events and the use of concomitant medications were monitored through day 7 ( \pm 2 days) (the day of the third visit, when laboratory tests were repeated). If patients did not have a response, they were given their usual migraine treatment, and the lack of response was recorded. Patients could be discharged at any time after the four-hour assessment. A safety officer at the central randomization center judged the tolerability and safety of all treatments in an unblinded fashion. All other parties involved in the study remained blinded until the study was completed and the data base locked.

\section{outcome measures}

The primary efficacy end point was a response, defined as the reduction of severe or moderate headache at base line to mild or no headache at two hours. Secondary end points were the rates of response 30 minutes and 1, 4, and 24 hours after the start of the infusion; the headache-free rates at 30 minutes and 1, 2, 4, and 24 hours after the start of the infusion; the rates of sustained response over a 24-hour period; the relief of nausea, vomiting, photophobia, and phonophobia; the time to mean-

\begin{tabular}{|c|c|c|c|c|c|c|c|c|}
\hline Group & $\begin{array}{l}\text { Total } \\
\text { No. }\end{array}$ & $\begin{array}{l}\text { Median } \\
\text { Age }\end{array}$ & $\begin{array}{l}\text { No. of } \\
\text { Women }\end{array}$ & $\begin{array}{l}\text { No. of } \\
\text { Men }\end{array}$ & $\begin{array}{c}\text { Median Time } \\
\text { since Diagnosis }\end{array}$ & $\begin{array}{l}\text { Median No. } \\
\text { of Attacks } \\
\text { in Past } 6 \text { Mo }\end{array}$ & $\begin{array}{l}\text { History of Attacks } \\
\text { with Aura }\end{array}$ & $\begin{array}{l}\text { Current Attack } \\
\text { Associated } \\
\text { with Aura }\end{array}$ \\
\hline & & $\gamma r$ & & & $\gamma r$ & & \multicolumn{2}{|c|}{ percent } \\
\hline BIBN 4096 BS & 85 & 47 & 71 & 14 & 20 & 18 & 27 & 12 \\
\hline $0.25 \mathrm{mg}$ & 1 & 43 & 1 & 0 & 29 & 6 & 0 & 0 \\
\hline $0.5 \mathrm{mg}$ & 4 & 42 & 3 & 1 & 15 & 15 & 25 & 25 \\
\hline $1 \mathrm{mg}$ & 20 & 49 & 18 & 2 & 20 & 19 & 25 & 5 \\
\hline $2.5 \mathrm{mg}$ & 32 & 45 & 29 & 3 & 19 & 18 & 25 & 13 \\
\hline $5 \mathrm{mg}$ & 16 & 52 & 13 & 3 & 28 & 26 & 38 & 13 \\
\hline $10 \mathrm{mg}$ & 12 & 47 & 7 & 5 & 25 & 12 & 25 & 17 \\
\hline Placebo & 41 & 47 & 29 & 12 & 22 & 24 & 34 & 12 \\
\hline
\end{tabular}


ingful relief; the degree of clinical disability; the use of rescue medication; the frequency of adverse events; and changes from base line in heart rate, blood pressure measured while the patient was supine, or clinical laboratory values.

\section{STATISTICAL ANALYSIS}

The response rate in the dose group, selected by means of the group-sequential adaptive treatmentassignment procedure, was compared with the response rate in the placebo group with the use of Fisher's exact test and a one-sided alpha level of 0.025 . At the planning stage, computer simulations were used to estimate the necessary statistical power and sample size for the trial. The resulting sample size was 130 to 150 patients. The trial was designed to have a statistical power of 80 percent, provided that at least one of the doses of BIBN 4096 $\mathrm{BS}$ produced a response rate of 60 percent or more and the response rate in the placebo group was 30 percent. In view of the inherent design bias in the observed rates of response (in particular, the possibility of overestimating the response to the selected dose), the actual type I error rate had to be estimated on the basis of the simulations; the error rate does not exceed the nominal level of 2.5 percent when response rates in the placebo group are 40 percent or less. Because of the unstratified nature of randomization and the small size of most dose groups, only descriptive methods were used in the secondary statistical analyses.

\section{RESULTS}

We screened 380 patients, and 127 presented during an acute migraine attack and underwent randomization. One of the 127 patients did not receive trial medication. The analysis of efficacy is thus based on all 126 treated patients. The demographic characteristics of the patients are summarized in Table 1. All patients were white.

\section{PRIMARY END POINT}

The primary end point was a response two hours after treatment. The up-and-down process, driven by the proportion of patients with a response in the preceding group, led to the selection of the $2.5-\mathrm{mg}$ dose of BIBN $4096 \mathrm{BS}$. The rate of response to this dose was 66 percent ( 21 of 32 patients), and the rate of response to placebo was 27 percent (11 of 41 patients, $\mathrm{P}=0.001$ ) (Fig. 1). Effects of the other doses are shown in Figure 1. A dif- ference in response rates between the BIBN 4096 BS group as a whole and the placebo group was apparent after 30 minutes (Fig. 2).

SECONDARY END POINTS

Pain-free rates are given in Table 2. The duration of the attack at the time of treatment did not differ sig-
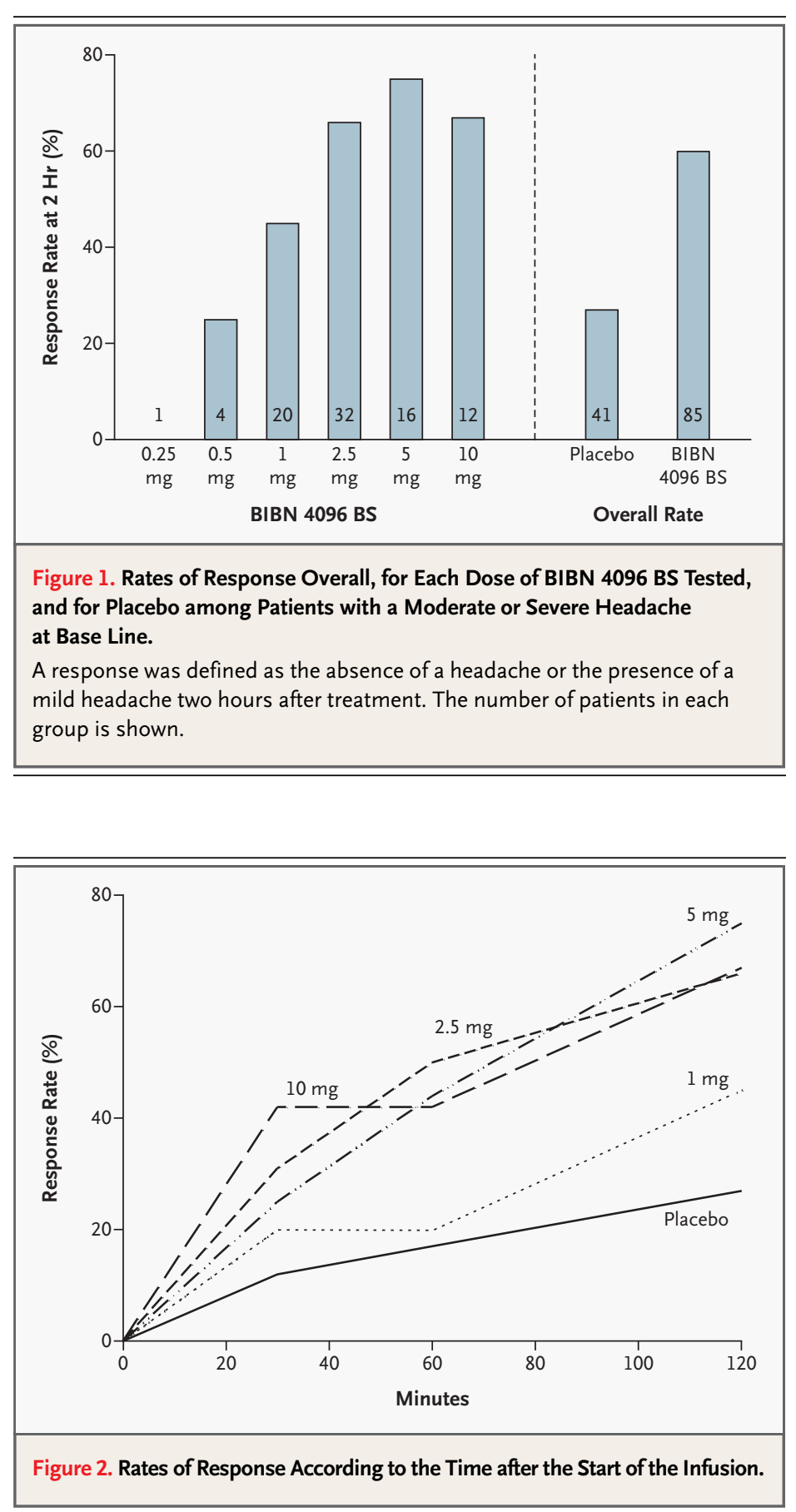


\begin{tabular}{|llllllll|}
\hline \hline $\begin{array}{l}\text { Table 2. Headache-free Rates According to the Time after the Start } \\
\text { of the Infusion. }\end{array}$ \\
\hline Group & Total No. & \multicolumn{5}{c|}{ Time after Start of Infusion } \\
& & $30 \mathrm{~min}$ & $1 \mathrm{hr}$ & $2 \mathrm{hr}$ & $4 \mathrm{hr}$ & $24 \mathrm{hr}$ \\
& & \multicolumn{5}{c}{ number of patients (percent) } \\
BIBN $4096 \mathrm{BS}$ & 85 & $3(4)$ & $10(12)$ & $25(29)$ & $34(40)$ & $40(47)$ \\
$0.25 \mathrm{mg}$ & 1 & 0 & 0 & 0 & 0 & 0 \\
$0.5 \mathrm{mg}$ & 4 & 0 & 0 & 0 & 0 & $2(50)$ \\
$1 \mathrm{mg}$ & 20 & 0 & $1(5)$ & $4(20)$ & $5(25)$ & $9(45)$ \\
$2.5 \mathrm{mg}$ & 32 & $1(3)$ & $5(16)$ & $14(44)$ & $18(56)$ & $15(47)$ \\
$5 \mathrm{mg}$ & 16 & 0 & $2(12)$ & $4(25)$ & $6(38)$ & $11(69)$ \\
$10 \mathrm{mg}$ & 12 & $2(17)$ & $2(17)$ & $3(25)$ & $5(42)$ & $3(25)$ \\
Placebo & 41 & $1(2)$ & $1(2)$ & $1(2)$ & $4(10)$ & $6(15)$ \\
\hline \hline
\end{tabular}

nificantly between those who had a response and those who did not have a response. Nausea, photophobia, phonophobia, and functional capacity all improved in parallel with the extent of response to treatment. The rate of recurrence was 19 percent among patients who received the 2.5-mg dose and 20 percent among the BIBN 4096 BS group as a whole, as compared with 46 percent among patients who received placebo. The rate of use of rescue medication was lower among patients who received BIBN 4096 BS than among those who received placebo.

\section{TOLERABILITY AND SAFETY}

The overall rate of adverse events was 20 percent in the BIBN 4096 BS group as a whole and 12 percent in the placebo group. In the group given $2.5 \mathrm{mg}$ of BIBN 4096 BS, 25 percent of the patients had at least one adverse event. The rates in the 1-mg group were similar. The most frequent adverse events are shown in Table 3. Paresthesias were relatively frequent but were mild. All other events occurred only in single patients. None of the patients had abnormal laboratory values that could be classified as adverse events.

\section{I SCUSSIO N}

We found that the nonpeptide CGRP-receptor antagonist BIBN 4096 BS is effective in treating migraine attacks up to six hours after onset. We were also able to provide a good estimate of the range of doses likely to be assessed in future clinical trials, while minimizing the exposure of patients to placebo.
CGRP is a potent vasodilator, particularly in the cerebral circulation. ${ }^{5}$ Isolated human pial arteries are approximately 10 times as sensitive to CGRP as middle meningeal arteries and 20 times as sensitive as subcutaneous arteries. ${ }^{19}$ CGRP is present in perivascular trigeminal-nerve fibers that supply the pial arteries, the meningeal arteries, ${ }^{20}$ and the extracranial cephalic arteries. ${ }^{21}$ Stimulation of the trigeminal ganglion in humans and cats ${ }^{22}$ and electrical stimulation of the superior sagittal sinus in animals ${ }^{23,24}$ induce the release of CGRP into the cranial circulation. During spontaneous migraine attacks, the level ofCGRP is increased in blood from the external jugular vein, which drains the extracranial compartment. ${ }^{8,25}$ The intravenous infusion of CGRP elicited migraine-like headaches in 8 of 10 patients with a history of migraine, and in 3 of 10 patients, this headache fulfilled the criteria for migraine without aura devised by the International Headache Society. ${ }^{9}$ Sumatriptan, an effective acute antimigraine treatment ${ }^{26}$ of the class of serotonin $5-\mathrm{HT}_{1 \mathrm{~B} / 1 \mathrm{D}}$-receptor agonists, ${ }^{27}$ normalizes elevated CGRP levels as it terminates a migraine attack, 25 an observation consistent with the clinical effect of BIBN 4096 BS that we observed. Thus, CGRP may have a role in both initiating and mediating migraine attacks.

BIBN 4096 BS blocks trigeminal-induced facial vascular dilatation in the marmoset ${ }^{10}$ and CGRPinduced dilation of both human and bovine cerebral vessels. ${ }^{11}$ Similarly, triptans can block meningeal vascular dilation, ${ }^{28}$ a response that involves CGRP7 and nitric oxide. ${ }^{29}$ Studies that have used microiontophoresis have shown that BIBN 4096 BS blocks activity in the trigeminocervical complex of the cat that is induced by CGRP, L-glutamate, or stimulation of the superior sagittal sinus. ${ }^{30}$ This effect is shared with ergot derivatives and triptans. ${ }^{31}$ In humans BIBN 4096 BS caused only minor adverse events ${ }^{32}$ and had no constrictor effect on the middle cerebral, radial, or superficial temporal artery or on regional cerebral blood flow, blood pressure, or heart rate. ${ }^{33,34}$ It antagonized the extracerebral effect of infused CGRP in humans. ${ }^{33}$ BIBN 4096 BS has not shown vasoconstrictor activity in several animal models or in human studies, and it is the first migraine-specific medication that is not a vasoconstrictor.

The rate of response to pain two hours after treatment - the main end point of the study — was significantly higher after the infusion of BIBN 4096 $\mathrm{BS}$ than after the infusion of placebo. The robust- 
ness of this primary conclusion was confirmed by the similarly positive results we found for all the secondary end points with the use of descriptive methods. Proof of concept was thus established. Despite the small number of patients in the study, it was possible to identify a narrow range of doses that should be used in future clinical trials. The effect on migraine pain was somewhat lower than the reported rate of response to injectable sumatriptan ${ }^{26}$ but corresponded to the best published results for oral triptans. ${ }^{35}$ The methods we used tend to overestimate the effect of the chosen dose, but on the other hand, our study required patients to be treated in a hospital, and they may have been rather refractory to treatment. Because of the relatively small sample and the special design of our study, the degree to which it can be compared with traditional designs is highly uncertain, although the pain-free rate at two hours of 44 percent and the rate of recurrence of 19 percent after the 2.5-mg dose of BIBN 4096 BS are promising when compared with these rates after treatment with triptans. ${ }^{35}$

We confirmed the favorable safety and tolerability results reported in a previous phase 1 study. 32 The overall rate of adverse events was low. All events were mild or moderate. Paresthesia was the only adverse event of note. BIBN 4096 BS does not seem to have vasoconstrictor properties, ${ }^{32}$ but our data base was too small for us to assess cardiovascular safety. If subsequent studies prove the drug to be without vasoconstrictor properties, this will represent an advantage over the triptans.

Our results pose some important clinical and fundamental pathophysiological questions. Would patients who have no response to triptans benefit from treatment with a CGRP antagonist, or would the benefit be confined to those who have a response to triptans? How would a CGRP antagonist and a triptan compare if studied contemporaneously? Given that CGRP antagonists have no direct vasoconstrictor effects, would this class of compounds offer similar efficacy and be safer than triptans? Can

\begin{tabular}{|c|c|c|c|}
\hline Adverse Event & $\begin{array}{l}\text { All BIBN } 4096 \text { BS Groups } \\
\qquad(\mathrm{N}=85)\end{array}$ & $\begin{array}{l}\text { Placebo Group } \\
\quad(N=41)\end{array}$ & $\begin{array}{l}\text { All Patients } \\
(\mathrm{N}=126)\end{array}$ \\
\hline & \multicolumn{3}{|c|}{ number (percent) } \\
\hline Paresthesia & $7(8)$ & 0 & $7(6)$ \\
\hline Nausea & $2(2)$ & $1(2)$ & $3(2)$ \\
\hline Headache & $2(2)$ & 0 & $2(2)$ \\
\hline Dry mouth & $2(2)$ & 0 & $2(2)$ \\
\hline Abnormal vision & $2(2)$ & 0 & $2(2)$ \\
\hline
\end{tabular}

CGRP antagonists establish the primacy of the nerve over the vessel during a migraine attack? Only future studies that use a more easily administered formulation of a CGRP antagonist can answer these questions, but our findings offer the prospect of both better treatment and a greater understanding of one of the most common clinical problems in medicine.

\section{Supported by Boehringer Ingelheim Pharma.}

Dr. Olesen reports having served as a consultant for AstraZeneca, Boehringer Ingelheim, GlaxoSmithKline, Pfizer, Lundbeck, and Johnson \& Johnson; receiving lecture fees from GlaxoSmithKline, Lundbeck, and Pfizer; and jointly holding patents with GlaxoSmithKline and Neurosearch. Dr. Diener reports having served as a consultant for GlaxoSmithKline, Pfizer, Lilly, Janssen-Cilag, 3M Medica, Novartis, Allergan, Almirall, Schaper \& Brümmer, Johnson \& Johnson, Pierre Fabre, and Weber \& Weber; receiving speaker's fees from AstraZeneca, GlaxoSmithKline, Pfizer, Boehringer, Bayer Vital, BristolMyers Squibb, Grünenthal, Janssen-Cilag, 3M Medica, Novartis, Pharmacia, Allergan, Almirall, Schaper \& Brümmer, Johnson \& Johnson, La Roche, Pierre Fabre, and Weber \& Weber; and receiving grant support from GlaxoSmithKline, Boehringer, Janssen-Cilag, Allergan, and Almirall. Dr. Goadsby reports having served as a consultant for Boehringer Ingelheim, Merck, GlaxoSmithKline, Pfizer, AstraZeneca, Allergan, OrthoMcNeil, and Vanguard; receiving lecture fees from Merck, Pfizer, Allergan, and OrthoMcNeil; and receiving grant support from GlaxoSmithKline and OrthoMcNeil. Dr. Husstedt reports having received consulting fees from Dupont and lecture fees from AstraZeneca, Aventis, Boehringer Ingelheim, Bristol-Myers Squibb, Ipsen, Merck Sharp \& Dohme, Schaper \& Brümmer, Bayer, Gilead, GlaxoSmithKline, Pfizer, Roche, and Schwabe. Drs. Hall, Meyer, Pollentier, and Lesko are employees of Boehringer Ingelheim.
REFERENCES

1. Lipton RB, Stewart WF, Diamond S, Diamond ML, Reed M. Prevalence and burden of migraine in the United States: data from the American Migraine Study II. Headache 2001;41:646-57.

2. Rasmussen BK, Olesen J. Symptomatic and nonsymptomatic headaches in a general population. Neurology 1992;42:122531.

3. Menken M, Munsat TL, Toole JF. The
Global Burden of Disease Study: implications for neurology. Arch Neurol 2000;57: 418-20.

4. Goadsby PJ, Lipton RB, Ferrari MD. Migraine - current understanding and treatment. N Engl J Med 2002;346:257-70.

5. Edvinsson L, Krause DN, eds. Cerebra blood flow and metabolism. 2nd ed. Philadelphia: Lippincott Williams \& Wilkins, 2002.
6. Jansen-Olesen I, Mortensen A, Edvinsson L. Calcitonin gene-related peptide is released from capsaicin-sensitive nerve fibres and induces vasodilatation of human cerebral arteries concomitant with activation of adenylyl cyclase. Cephalalgia 1996;16: 310-6.

7. Williamson DJ, Hargreaves RJ, Hill RG, Shepheard SL. Intravital microscope studies on the effects of neurokinin agonists and cal- 
citonin gene-related peptide on dural blood vessel diameter in the anaesthetized rat. Cephalalgia 1997;17:518-24.

8. Goadsby PJ, Edvinsson L, Ekman R. Vasoactive peptide release in the extracerebral circulation of humans during migraine headache. Ann Neurol 1990;28:183-7.

9. Lassen LH, Haderslev PA, Jacobsen VB, Iversen $\mathrm{HK}$, Sperling $\mathrm{B}$, Olesen J. CGRP may play a causative role in migraine. Cephalalgia 2002;22:54-61.

10. Doods H, Hallermayer G, Wu D, et al. Pharmacological profile of BIBN4096BS, the first selective small molecular CGRP antagonist. Br J Pharmacol 2000;129:420-3.

11. Moreno MJ, Abounader R, Hebert E, Doods H, Hamel E. Efficacy of the non-peptide CGRP receptor antagonist BIBN4096BS in blocking CGRP-induced dilations in human and bovine cerebral arteries: potentia implications in acute migraine treatment. Neuropharmacology 2002;42:568-76.

12. Headache Classification Subcommittee of the International Headache Society. The International Classification of Headache Disorders (second edition). Cephalalgia 2004; 24:Suppl 1:1-160

13. Jennison C, Turnbull BW. Group sequential methods with applications to clinical trials. Boca Raton, Fla.: Chapman \& Hall/CRC, 2000.

14. Moller S. An extension of the continua reassessment methods using a preliminary up-and-down design in a dose finding study in cancer patients, in order to investigate a greater range of doses. Stat Med 1995;14. 911-22.

15. Roon KI, Olesen J, Diener HC, et al. No acute antimigraine efficacy of CP-122,288, a highly potent inhibitor of neurogenic inflammation: results of two randomized, double-blind, placebo-controlled clinical trials. Ann Neurol 2000;47:238-41.

16. Hróbjartsson A, Gøtzsche PC. Is the placebo powerless? An analysis of clinical trials comparing placebo with no treatment N Engl J Med 2001;344:1594-602. [Erratum, N Engl J Med 2001;345:304.]

17. Tfelt-Hansen P, Block G, Dahlof C, et al
Guidelines for controlled trials of drugs in migraine: second edition. Cephalalgia 2000; 20:765-86.

8. Bendtsen L, Mattsson P, Zwart JA, Lipto RB. Placebo response in clinical randomized trials of analgesics in migraine. Cephalalgia 2003;23:487-90.

19. Jansen I, Uddman R, Ekman R, Olesen J, Ottosson A, Edvinsson L. Distribution an effects of neuropeptide $Y$, vasoactive intestinal peptide, substance $P$, and calcitonin generelated peptide in human middle meningeal arteries: comparison with cerebral and temporal arteries. Peptides 1992;13:527-36. 20. Uddman R, Edvinsson L, Ekman R, Kingman T, McCulloch J. Innervation of the feline cerebral vasculature by nerve fibers containing calcitonin gene-related peptide trigeminal origin and co-existence with sub stance P. Neurosci Lett 1985;62:131-6.

21. Jansen I, Uddman R, Hocherman M, et al. Localization and effects of neuropeptide $\mathrm{Y}$, vasoactive intestinal polypeptide, substance $\mathrm{P}$, and calcitonin gene-related peptide in human temporal arteries. Ann Neurol 1986;20:496-501.

22. Goadsby PJ, Edvinsson L, Ekman R. Release of vasoactive peptides in the extracerebral circulation of human and the cat during activation of the trigeminovascular system. Ann Neurol 1988;23:193-6.

23. Zagami AS, Goadsby PJ, Edvinsson I. Stimulation of the superior sagittal sinus in the cat causes release of vasoactive peptides. Neuropeptides 1990;16:69-75.

24. Buzzi MG, Carter WB, Shimizu T, Heath H III, Moskowitz MA. Dihydroergotamine and sumatriptan attenuate levels of CGRP in plasma in rat superior sagittal sinus during electrical stimulation of the trigeminal ganglion. Neuropharmacology 1991;30:1193 200.

25. Goadsby PJ, Edvinsson L. The trigeminovascular system and migraine: studies characterizing cerebrovascular and neuropeptide changes seen in humans and cats. Ann Neurol 1993;33:48-56.

26. The Subcutaneous Sumatriptan International Study Group. Treatment of migraine attacks with sumatriptan. N Engl J Med 1991; 325:316-21.

27. Goadsby PJ. The pharmacology of headache. Prog Neurobiol 2000;62:509-25.

28. Williamson DJ, Hargreaves RJ, Hill RG, Shepheard SL. Sumatriptan inhibits neurogenic vasodilation of dural blood vessels in the anaesthetized rat - intravital microscope studies. Cephalalgia 1997;17:525-31.

29. Akerman S, Williamson DJ, Kaube $\mathrm{H}$, Goadsby PJ. Nitric oxide synthase inhibitors can antagonize neurogenic and calcitonin gene-related peptide induced dilation of dural meningeal vessels. Br J Pharmacol 2002; 137:62-8.

30. Storer RJ, Akerman S, Goadsby PJ. Blockade of calcitonin gene-related peptide (CGRP) receptors in the trigeminocervical complex reduces trigeminovascular nociceptive traffic. Cephalalgia 2003;23:726. abstract.

31. Storer RJ, Goadsby PJ. Microiontophoretic application of serotonin $(5 \mathrm{HT})_{1 \mathrm{~B} / 1 \mathrm{D}}$ agonists inhibits trigeminal cell firing in the cat. Brain 1997;120:2171-7.

32. Iovino M, Feifel U, Yong C-L, Wolters J-M, Wallenstein G. Safety, tolerability, and pharmacokinetics of BIBN 4096 BS, the first selective small molecular calcitonin generelated peptide receptor antagonist, following single intravenous administration in healthy volunteers. Cephalalgia (in press). 33. Petersen KA, Lassen LH, Birk S, Olesen J. The effect of the nonpeptide CGRP-antagonist, BIBN4096BS on human-alphaCGRP induced headache and hemodynamics in healthy volunteers. Cephalalgia 2003;23:725. abstract.

34. Petersen KA, Birk S, Lassen LH, Kruuse C, Jonassen O, Olesen J. The novel CGRPantagonist, BIBN4096BS does not affect the cerebral hemodynamics in healthy volunteers. Cephalalgia 2003;23:729. abstract. 35. Ferrari MD, Roon KI, Lipton RB, Goadsby PJ. Oral triptans (serotonin $5-\mathrm{HT}_{1 \mathrm{~B} / 1 \mathrm{D}}$ agonists) in acute migraine treatment: a meta-analysis of 53 trials. Lancet 2001;358: 1668-75.

Copyright (c) 2004 Massachusetts Medical Society.

PERSONAL ARCHIVES IN THE JOURNAL ONLINE

Individual subscribers can store articles and searches using a feature on the Journal's Web site (www.nejm.org) called "Personal Archive." Each article and search result links to this feature. Users can create personal folders and move articles into them for convenient retrieval later. 